\title{
The Nation of Islam
}

\author{
Edward E. Curtis IV
}

Established in 1930 in Detroit, Michigan, by W.D. Fard Muhammad (1893-?), the Nation of Islam (henceforth NOI) grew after World War II to be the most important and controversial Islamic new religious movement in the United States and the Anglophobe Black world. Tens of thousands, perhaps over one hundred thousand African Americans joined the movement, but it garnered the sympathy and tacit support of many more African Americans for its emphasis on Black pride and self-determination. By the 1970s, the number of NOI religious congregations numbered seventy, and its businesses generated tens of millions of dollars in revenue (Curtis 2006: 2-4).

The NOI taught that Islam was the original religion of Black people stolen from them during the era of the trans-Atlantic slave trade, and beckoned them to abandon Christianity, which the movement said had bound them in both physical and mental chains. Introducing an original form of Islamic religion that interpreted historically Islamic traditions through the prophecies of its charismatic leader, Elijah Muhammad, the NoI advocated separate Black businesses, schools, neighborhoods, and a state. Though it used revolutionary theological rhetoric, it eschewed both war and violence. Instead, the NoI focused on achieving its goals through the reformation of Black American minds and bodies. Membership in the Nor required careful study and practice of Elijah Muhammad's teachings, which combined Islamic themes with twentiethcentury metaphysical religion, including a belief in UFOs, to produce a version of Islam that included novel theological, cosmological, and eschatological doctrines as well devotion to a strict code of middle-class, socially conservative ethics (Curtis 2016). From an historically Islamic perspective, one of the most controversial of these teachings was the belief that W.D. Fard was God in the flesh, and that Elijah Muhammad was the Messenger of God-a claim that contradicted both Sunnī and Shī'a Islamic traditions (Curtis 2006: 10-14).

Though representing a tiny sliver of the global Muslim community, the men and women of the NOI played an outsized role in US politics as they voiced some of the fiercest and most effective opposition to US imperialism, 
especially the Vietnam War, in the twentieth century. This chapter will detail the NOI's origins and development, paying attention to important charismatic figures such as Malcolm $x$ and Muhammad Ali. It will then outline its religious teachings and practices. Finally, it will detail the split of the movement into two main branches after the death of leader Elijah Muhammad in 1975; one led by W.D. Mohammed and the other led by Louis Farrakhan.

Scholars continue to debate the background of the NoI's mysterious founder, W.D. Fard or Farad Muhammad (Evanzz 20o1; Turner 2003). An itinerant salesman who went door-to-door in Black Detroit, Fard peddled Oriental silks and shared secrets with his clients about their origins. He told them that they were originally from the Holy City of Mecca in Arabia, and their original language was Arabic. Echoing the claims of Black intellectuals such as Edward W. Blyden and many African American religious and cultural leaders of the 1920s, Fard linked the history of Black people to Islamic civilisation. He established a temple devoted to this teaching in Detroit, where Elijah Poole Muhammad (18971975) of Sandersville, Georgia, became his student and an important aide. But by 1934, Fard had permanently left Detroit, and after some struggle for the leadership of the group, Elijah Muhammad emerged as its leader (Clegg 1997).

Even though Elijah Muhammad gave credit for all of his teachings to W.D. Fard, claiming that his prophecies came directly from God Himself, it seems clear from historical records that many of the Messenger's teachings were passed on to organisation members long after Fard had left. One of these doctrines, for example, may have been the claim that Fard was Allāh, or God, in person. It is more likely that Fard believed he was the Christian Messiah and the Islamic Mahdī, figures who, according to Islamic tradition, will appear near the time when the world will end. This idea has been circulating among various African American new religious movements of the 1920s, and members of the Ahmadiyya movement had been making such claims about their own founder, Mirza Ghulam Ahmad, for decades (Curtis 2002: 63-84).

More than any other person, Elijah Muhammad was responsible for the unique teachings of the NOI. Raised during the Jim Crow era of racial segregation in the Deep South, Elijah Muhammad traveled north during the Great Migration of over one million and half people between World Wars I and II. He worked alongside African Americans and immigrants alike at the Chevy Axle Company but became unemployed during the Great Depression, when 
he met Fard. After Fard left in 1934, Elijah Muhammad not only faced competition for the leadership of the movement but also ran afoul of federal authorities (Curtis 2002: 63-84).

Like many African American leaders of both traditional and new religious movements, Elijah Muhammad was investigated by the US Federal Bureau of Investigation (FBI) for sedition. For FBI director J. Edgar Hoover, almost any agitation for equal rights was seen as potentially seditious. But Hoover was especially concerned about the advocacy of many new religious movement leaders such as Mittie Maud Lena Gordon on behalf of the Empire of Japan. Elijah Muhammad was also implicated as a possible ally of the Japanese, whom he considered to be fellow people of color. But the government managed to convict him only of draft evasion, not sedition (Curtis 2013).

As he served time in a federal penitentiary from 1943 to 1946, his spouse, Clara Muhammad, is credited with keeping the movement's members connected to its leader and to keeping the movement alive. It was after Elijah Muhammad emerged from prison that the movement distinguished itself from the dozens of Islamic groups and new religious movements seeking the patronage of African Americans. As the United States emerged as a predominant global power that advocated freedom of religion and speech and economic opportunity in its Cold War with the Soviet Union, the NOI attempted to expose the white supremacist social system that used both legal and extralegal means to insure the second-class citizenship of Black people in the United States. Elijah Muhammad criticised African American civil rights leaders saying that their advocacy of racial integration would not correct the problem, and he advocated instead religious and political separatism. He instructed his followers to avoid service in the US military and he told them not to vote in elections. As one of the chief US critics the civil rights movement in the late 195os and early 196os, Elijah Muhammad did not share Martin Luther King Jr.'s dream of racial brotherhood with the people whom he called "blue-eyed devils." Instead, Elijah Muhammad dreamed of racial justice, which he said would come when God would send fire and brimstone to destroy white America in an imminent racial apocalypse. Since God would eventually see justice done, Elijah Muhammad taught, it was not the job of his followers to stage a violent revolution against white America. He told them to obey US laws unless they conflicted with their freedom to practice their religion. Though the NOI advocated self-defense, the movement did not advocate aggressive violence and it did utilise the US courts to defend its religious liberty, especially the rights of Muslim prisoners to practice Islam (Curtis 2002: 63-84).

This lack of a direct challenge to the US political system and white neocolonialism more generally was a frustration for Malcolm x (1922-1965), Elijah 
Muhammad's chief lieutenant. Born Malcolm Little in Omaha, Nebraska, Malcolm X converted to the NOI while in prison, and became the movement's most effective organiser and spokesperson during the 1950s. Serving as an NOI minister at Temple No. 7 in Harlem, New York, Malcolm x helped to link the movement to the burgeoning Afro-Asian solidarity and non-aligned movements of developing countries that opposed both US and Soviet interference in their internal affairs. Malcolm $x$ articulated the dreams of many Black Americans for pan-Africanism, the movement to create cultural and political unity among all people of African descent. He was also a strong supporter of Egyptian President Gamal Abdel Nasser, whom he later saw as a model Muslim political leader (Curtis 2015). As a result of his fiery rhetoric and his intellectual creativity, Malcolm $\mathrm{x}$ became a media fascination, especially after Mike Wallace of свs News featured him as part of a 1959 television special on the movement entitled The Hate that Hate Produced. Like other liberals, including the Rev. Dr King, Mike Wallace explained the popularity of the NOI as the product of poor race relations or what sociologist of religion C. Eric Lincoln would analyze in The Black Muslims in America (1961) as a form of psychological and social compensation and the expression of black resentment (Lincoln 1961).

In 1963, Elijah Muhammad suspended Malcolm x for disobeying an order not to comment on the assassination of President John F. Kennedy. Malcolm X formerly separated from the NOI in 1964 , when he converted to Sunnì Islam and went on the hajj, or pilgrimage to Mecca. He took a new name, El-Hajj Malik El-Shabazz. Shabazz also toured several sub-Saharan African countries but devoted even more time to studying Islamic religion in Egypt and Saudi Arabia. Freed from the constraints of the NOI, he founded the Organization of Afro-American Unity and articulated the need for revolution and the use of violence if necessary to free Black and other oppressed people from oppression, racism, and neocolonialism. At the same time, Malik Shabazz sought to develop his New York-based Muslim Mosque, Inc., into a viable African American Sunnī Muslim organisation. But before either organisation could develop further, Shabazz was assassinated in February 1965 (Curtis 2015).

As significant as Malcolm x's assassination was, it did not impede the growth of the NOI in the second half of the 196os. The NOI's most famous convert, world heavyweight-boxing champion Muhammad Ali, remained loyal to Elijah Muhammad and when, in 1967, at the height of the Vietnam War, he refused to be inducted into the US Army, the NOI gained stature among people of color around the world as a space of radical protest against US foreign policy and especially military occupation in the developing world. Ali claimed that it went against his religious principles to fight in Vietnam and he decried the 
hypocrisy of a US government trying to protect freedom abroad when it had not achieved freedom at home for Black people. Ali's boxing license was taken away, and like his leader Elijah Muhammad, he prepared to face prison time rather than serving in the US military. Even as the NOI continued to avoid any direct challenge to the state, the symbolic protest of Ali's refusal to fight and his reasons for not doing so were viewed by supporters and detractors alike as a form of radical politics (Curtis 2006: 1-14).

Public figures such as Malcolm x and Muhammad Ali helped to produce popular, scholarly, media, and governmental images of the NOI as a radical political group. And NOI made a significant political impact in postwar US history. But such images often cloud or even overshadow the strongly religious character of a movement that rested on clearly articulated religious doctrines, a charismatic prophet, religious ethics, a system of rituals, and a vibrant material religious culture. Examining these religious elements and how they intersected with or were coterminous with the movement's politics are essential to understanding why the NOI worked as a mass movement. The NOI offered its followers meaning and purpose and a clear path toward religious liberation.

The first step toward this liberation, Elijah Muhammad taught, was knowledge of self; the real history of Black man that white people had suppressed. Many members who converted to the NOI said and wrote that they found Islam to be a more rational and scientific religion than Christianity. Even if many of the theological claims of the NOI were no more based on modern science than those of many Christian groups, NOI members presented their religion as grounded in material reality. They criticised the doctrine of the Trinity (the Christian belief that God is three persons, Father, Son, and Holy Ghost) as irrational. Their belief that God was a human being, not some "spook in space," exemplified the NOI belief that their religion was grounded in fact rather than fiction. The same was true for their belief that heaven and heaven were not actual places, but states of mind - a belief shared by many other metaphysical religions in the twentieth century (Curtis 2006: 16-24).

NOI catechisms entitled 'Actual Facts', the 'Rules of Islam', and 'Student Enrollment', memorised by both male and female followers, offered both astronomical fact and cosmological theory. For example, 'Actual Facts' detailed the various distances between planets in the solar system and the Sun as well as the total square mileage of land on the Earth. In explaining the separation of the Moon from the Earth, this catechism credited a scientist with creating an 
explosion sixty-six trillion years ago. Indeed, the belief that scientists' mastery of technology was behind most cosmological events was central to Elijah Muhammad's thought. Like Christian fundamentalists, he agreed with the idea that the current historical dispensation, or the reign of white civilisation, began 6,ooo years ago, but he argued that the actual origins of humanity-that is, Black humanity - could be dated to trillions of years ago (Curtis 2016).

No matter how esoteric Elijah Muhammad's teachings may have seemed to those outside the movement, these lessons attempted to give concrete reasons for the relative lack of social, cultural, and political power among Black people, and offer the means to Black empowerment. The fullest published expression of his theology was in his 1965 opus, Message to the Blackman in America. In explaining the origins of slavery and racism, Elijah Muhammad offered a unique myth, sometimes called 'the Myth of Yacub'. Referring to archeological and anthropological discoveries on the African continent, Elijah Muhammad said that the original man - the first human species—was Black. These Black people, who followed the religion of Islam, lived in Mecca, he said, where they existed in an Edenic state. But a mad scientist named Yacub began the process of genetically engineering the white man, who was naturally brutish and rapacious. White people eventually conquered the Black people, and Black/ Muslims forgot their language, Arabic, and their true religion. They adopted the religion of their slave masters. These enslaved Black people gave up their dignified, respectable behaviors, the Messenger taught. They ate poorly, became sexually promiscuous, became lazy, and accepted their lot in life. But God would not abandon God's people. The appearance of W.D. Fard to Elijah Muhammad promised to change this history. Commissioned by Fard to "mentally resurrect" Black people, Elijah Muhammad would bring Black people back to Islam. They would separate from their slave masters and live righteously again. They could again live in a state of heavenly contentment if they would follow the Messenger's strict program of self-improvement (Muhammad 1972; Curtis 2006: 68-93).

Much of this ethical program of uplift focused on strengthening, purifying, and disciplining the Black body, which was tied to the fate of the entire Black race. For example, members of the NOI devoted a great deal of energy to their diet. According to Elijah Muhammad, NOI Muslims should avoid all pork and liquor-like other Muslims-but also the foods that came to be associated with the shameful legacy of slavery such as "lima beans, butter beans, blackeyed peas, green cabbage collard greens, pinto beans, kidney beans, brown field beans, cornbread, carp, catfish, crustaceans, mollusks, rabbit, possum, squirrel, [and] coon" (Curtis 2006: 98). Other beans were fine, and indeed the movement became known for selling bean pies, which were often made from 
navy beans. Red meat should be limited, and the Messenger exhorted followers to give up refined sugar, which, he said, was increasing diabetes among African Americans. He also asked followers to limit their overall caloric in-take and eat only one meal a day. Ramadan was practiced in the movement, but during Advent rather than during the actual Islamic (lunar) month of Ramadan. Elijah Muhammad explained that a Yuletide practice of Ramadan would help focus his followers' attention on Islam rather than Christianity during the holiday season. Eventually, all of the Messenger's teachings on diet were compiled into a monograph entitled How to Eat to Live (1972). Various columns and letters in the movement newspaper, Muhammad Speaks, outlined the health advantages of following this diet, and many believers testified to how following a strict diet could cure various bodily ailments (Curtis 2006: 98-109).

In addition to providing guidelines on how to eat, the movement became an incubator of food businesses that focused on providing healthy and wholesome food to the Black community overall. Elijah Muhammad himself owned several farms, a dairy, a meat processing plant, and by the 1970s, a multi-million dollar fish import business called Whiting H \& G. NOI followers were not only employed in these businesses but also established their own restaurants, bakeries, and groceries. Women in the NOI became known for selling homemade goods, especially the bean pie, around NOI places of worship, during NOI events, and in their homes and neighborhoods (Curtis 2006: 98-109).

Dress, fashion, and adornment were also essential to the NOI's focus on the ethics of the Black body. Unlike the teachings on food, many of these teachings emphasised the movement's central focus on properly gendered nature of male and female Black bodies. In the case of both men and women, Black Muslims were to dress in a respectable, dignified, and modest manner. But much of the discussion of dress in the movement centered on women's bodies. Many female writers in the Muhammad Speaks beckoned women to stop imitating what they regarded as white fashions. They proclaimed that wearing cosmetics and short skirts, bleaching skin, and dying hair obscured the natural beauty of Black women. Eschewing conventional fashion was a religious issue, as Sister Beverly $3 \mathrm{X}$ wrote in a poem: "Years ago, hemlines were not too short, but the clothes fit tight / I thought I was really all right. / A stone fox? No! An ignorant fool, following the devil's evil rule" (Curtis 2006: 114). Elijah Muhammad went even further when African American women in the 1970s began to wear afros. He banned them from the movement, and one of his female columnists said that African people did not actually wear their hair in this manner. To be naturally Black, it was said, was to be more civilised than wearing 'savage' styles like the afro. 
As much as dress and fashion focused on the female Black body, the NoI's program of moral reform concerning sexuality and reproduction did so even more. The official teaching of the movement was that men and women were equally responsible for sexual morality, which was defined as heterosexual married monogamy. Men in the movement were shamed and punished for sex outside wedlock and for adultery, especially with white women. But it was once again women's bodies that were often the focus of the Nor's official teachings about sexuality. Muhammad Speaks discussed women's bodies as the field in which the seeds of the Black nation must be planted. Elijah Muhammad talked about birth control as a form of Black genocide. Women were told to have large families in order to repopulate the race. Not all women in the movement followed the teachings about birth control, but it is also clear that patriarchy of the NOI was attractive to many of its female members. In the 1960 s and 1970s, African American women remained extremely vulnerable to sexual violence from both white and African American men. The promise of physical protection, which sometimes included escorts from the home to the mosque, made some NOI women feel safe. Moreover, Black women's safety was under threat from the state. One primary example of state violence against African American women was forced sterilisation, especially of poor African American women. This is one of the key contexts in which to understand why, even as second-wave feminism and the movement for the Equal Rights Amendment gained ground, tens of thousands of African American women would choose to support a sexually conservative movement like the NOI (Curtis 2006: 118-130).

Men and women also often operated inside the movement in separate spheres. Men participated in the Fruit of Islam, a fraternal organisation that insured movement discipline, provided security for NOI events, and arranged for the selling of movement newspapers. The Fruit of Islam was organised in military fashion: men inside the group possessed various military ranks and they were taught military salutes and protocols. The Fruit, as they were sometimes called, were much more than a self-defense force. It provided a male space for the teaching of NOI religious texts and catechisms as well as activities such as woodworking. In the 1960 s and 1970s, members were told to sell a certain number of copies of Muhammad Speaks newspapers each week, and sometimes developed entertaining, even aggressive sales techniques to hawk their newspapers on the streets of Black America. NOI women were enrolled in Muslim Girls Training-General Civilization, which taught cooking, sewing, spelling, penmanship, hygiene, child-rearing, and other subjects thought to be essential to being a wife and mother. Women sometimes learned to march in military fashion and maintained various military ranks. Like the Fruit, Muslim 
Girls Training enforced the ethical commandments of Elijah Muhammad, punishing those who wore the wrong clothes or had sex out of wedlock. Indeed, Sister Captains, as they were called, could be known to be harsh toward those under their authority. But there is also ample evidence that women often resisted their authority or simply ignored them (Curtis 2006:132-153).

In addition to establishing its own businesses and groups such as the Fruit of Islam, the NOI created what was in the 196os was the largest Muslim parochial system in the United States. Called the 'University of Islam', dozens of private schools offered a regular school curriculum in addition to classes on Arabic language and the religious teachings of Elijah Muhammad. The leaders of this school system were women, many of whom had professional experience in the public-school system. Though the schools enforced the socially conservative gender norms of the movement, they also encouraged both male and female achievement. Various issues of Muhammad Speaks featured the achievements of girls not only in subjects such as English and home economics, but also in math and science. The prominence of female educational leaders and awardwinning female students in University of Islam system are important indicators of the schools' commitment to the public presence of Muslim women and girls within the community itself (Curtis 2006: 153-16o).

Bodily discipline, Black knowledge, punctuality, modesty, patriarchy-and pageantry - were also featured in the public-facing ritual gatherings of the NOI. The ritual highlight of the year was Saviour's Day, the annual celebration of W.D. Fard on 26 February. Thousands of NOI members would come from across the country, joined by visitors, to celebrate the day in Chicago. In 1965, for example, attendees were able to observe an exhibition by boxer Muhammad Ali, testimonies from members of the Fruit of Islam and Muslim Girls Training, jazz music from Osman Karriem, and addresses by the Messenger himself. In addition to attending the Saviour's Day celebration, thousands of Muslims traveled long distances to see their leader in various rallies across the country. These carefully choreographed rallies treated Elijah Muhammad like a head of state as the Fruit of Islam carefully escorted him to the podium and maintained their posts with great discipline throughout the leader's long lectures (Curtis 2006:160-167).

Unlike African American Christian preachers who use what has been called the 'chanted sermon', Elijah Muhammad possessed a plain-speaking style, sometimes even stuttering as explained his teachings. His charisma did not come from his own personal style, but rather from the sobriety and truth that his words illustrated. Elijah Muhammad embodied his own critique of what he regarded as Black Christianity's emotionalism. To many outsiders, Muhammad was regarded as a boring, often rambling speaker. His charisma came instead 
from the respect and devotion of tens of thousands to his prophetic utterances and his person. They regarded him a genuine prophet, and if his teachings did not make sense on an initial hearing, this was the result of their lack of understanding, not his lack of explanatory skill (Curtis 2006: 16o-167).

Toward the end of his life, Elijah Muhammad began to make plain or perhaps reinterpret the meanings of some of his prophecies. This was especially true for his prophecy that the world would be destroyed by a Mother Plane, which he compared to Ezekiel's wheel (Ezekiel 1:16). Like his teachings about the origins of the Earth and of humankind, his proclamations about the end of white America were heavily invested in technological explanations of salvation history. In 1972, during a television interview, he revealed that the end of white supremacy would not equate into the end of white people. "I must tell the truth," he explained. "there will be no such thing as the elimination of all white people from the earth." In his other works, including The Supreme Wisdom (1957) and The Fall of America (1973), the Messenger explained or at the least implied that what would be eliminated was not white people, but the whiteness in people - the genetic or moral poison that created racism and violence. The appearance of the Mother Ship would be like medicine. The Mother Ship would reign down fire upon humanity, but such fire was a spiritual technology of righteousness. If people were willing to take this spiritual medicine, humankind could rediscover its Blackness, that is, its original goodness, and live in peace and harmony. Though the NOI did much to further a dark and angry religious vision of the racial apocalypse, Elijah Muhammad's religious teaching was in the end a utopian vision of human solidarity (Curtis 2016).

In February 1975, Elijah Muhammad died, and though he never publicly named a successor, it was son, Wallace D. Muhammad (also spelled W.D. Mohammed, 1933-2008) who emerged as the Nor leader at that year's Saviour's Day convention. In just a few short years, Imam Mohammed, as he would eventually be known, radically altered key characteristics of the movement. In short, he transformed the NOI from a new religious movement into an African American Sunnī Muslim religious denomination. Mohammed abandoned the NOI profession of belief in W.D. Fard as God and his father as a prophet. In its place, the leader asked his follower to recite the shahada, or the profession of belief that there is no god but God and Muhammad (of Arabia) is the Messenger of God. He instructed his followers to pray five times a day, to observe the holy month of fast during the Islamic month of Ramadan, and to go on hajj. Mohammed 
also eventually disbanded the Fruit of Islam and Muslim Girls Training, partly because he no longer wanted to use these groups to enforce the strict moral rules of the movement. From this point on, believers would answer to God and their own conscience for their behavior (Curtis 2002: 107-127).

Mohammed's approach to US politics and society was just as radical. Like his father before him, Mohammed had refused to serve in the US military and spent time in prison rather than take even a non-combat role. But as a leader, Imam Mohammed encouraged his followers to volunteer for military service. Over the next few decades, many of his followers would become the most highly ranked Muslim members of the US military and Imam Mohammed himself would be honored at the Pentagon, the Department of Defense headquarters, for his commitment to the US military after the first Gulf War. The Imam even introduced US flags in NOI mosques (Curtis 2002: 107-127).

Instead of encouraging racial separatism, Imam Mohammed invited white people to join the NOI, and participated in various interfaith cooperation efforts, most prominently in the Roman Catholic Focolare movement. To symbolise the new stance of the NOI, Imam Mohammed changed the name of the group to the World Community of al-Islam in the West. The organisation would go through more name changes, being called the American Muslim Mission and the American Society of Muslims until eventually it became known simply as the W.D. Mohammed community. Mohammed also divested himself of his father's business empire, and eventually handed over control of all mosque properties to each congregation. He did not wish to be in charge of a business, he said; he wanted to be a religious leader (Curtis 2002: 107-127).

There were also some continuities with his father's NOI. Imam Mohammed continued to stress the appeal of the movement to African Americans and celebrated historical Black achievements in Islamic and US history. The 1970s witnessed a popular Black ethnic revival, and Imam Mohammed participated in the movement to honor African American roots by asking his followers to call themselves 'Bilalians', after the Black companion of the Prophet Muhammad and first prayer-caller of Islam, the freedman, Bilal ibn Rabah. The name of the newspaper was also changed from Muhammad Speaks to Bilalian News. Imam Mohammed renamed the parochial schools of the movement, calling them the Clara Muhammad Schools after his mother, whom he discussed as an important African American historical figure (Curtis 2002: 107-127).

All of these changes were called the 'Second Resurrection' and Imam Mohammed told NOI members that W.D. Fard and his father had intended for them to occur all along. Many, if not most NOI members stayed with him through these changes. As NOI businesses ceased operations and the entrepreneurial activities tied to each congregation declined, followers nonetheless 
expressed palpable excitement over the change and committed themselves with fervor to observing Sunnī Islamic religious practices.

But some members rejected Imam Mohammed's changes, and the most important of these dissidents was Minister Louis Farrakhan (b. 1933). Minister Farrakhan rose to prominence in the NOI as Elijah Muhammad's chief spokesperson after Malcolm $x$ left the movement in the 196os, and he was rumored to have been one of the candidates to lead the movement after Elijah Muhammad died. He publicly declared his allegiance to W.D. Mohammed in 1975, but by 1978, broke with the new leader because of the radical departure from NOI teachings (Curtis 2002: 129-135).

Minister Farrakhan set about rebuilding a version of the original NOI based on the original teachings. In 1979, Minister Farrakhan established a newspaper, The Final Call, and bow-tied Fruit of Islam members could once again be seen in urban, African American neighborhoods offering it for sale. He eventually purchased Elijah Muhammad's home in Chicago and the NoI's largest mosque in Chicago, which he renamed Mosque Maryam. He also set about rebuilding movement businesses, and the Fruit of Islam became a private security service for hire, gaining some contracts to protect public housing programs. A significant number of African Americans who lived in neighborhoods affected by the drug epidemic of the 1980s praised their performance; the Fruit of Islam symbolised and helped to further Black safety and dignity. Farrakhan also became a vocal critic of gang-banging and of how AIDS was disproportionately killing Black people. He advocated the practice of a clean living, socially conservative, and patriarchy as solutions for these social problems, but also blamed the US government and racism as the agents behind the problems of African Americans (Gardell 1996).

Farrakhan's NOI was just as uncompromising a critic of the US government as Elijah Muhammad's NOI had been, though Farrakhan still told followers to obey US laws and avoid any revolutionary activities. Like Elijah Muhammad's NOI, the new organisation sought ties with foreign Muslim governments, including those of Qaddafi's Libya and the Islamic Republic of Iran. In the 1980s, the group was highly critical of Jewish anti-Black racism. Farrakhan's anti-Semitic comments - and those of other NOI ministers-sparked outrage among Jewish Americans, and the Southern Poverty Law Center, a liberal American think-tank that tracks racist groups, eventually labeled the new NOI a "hate group" (Gardell 1996).

But this public opprobrium did not lessen Farrakhan's appeal to many African Americans. Though his NOI remained a small movement in terms of card-carrying members, perhaps numbering in the tens of thousands at its height, Farrakhan himself and the movement's resistance to white supremacy 
appealed to a far larger number of Black Americans, thousands of whom would travel to see Farrakhan speak in various US cities. His greatest success in this regard was the 1995 Million Man March in Washington, D.C., where hundreds of thousands of Black men would crowd the nation's mall not only to protest anti-Black racism but also to renew their commitments to themselves and other Black men for unity and self-improvement. Farrakhan's address delved into numerology and Freemasonry, but the bulk of the address outlined a multi-step program for personal improvement. His leadership of the march also represented a turn toward more inter-racial and ecumenical thinking. The Unification Church of the Rev. Sun Myung Moon cosponsored the march, and Minister Farrakhan addressed people of all races in calling for world peace and justice. Quoting from the Qurān, he proclaimed that one race is not superior to another: "It doesn't matter what your color is, your race is, with God it is righteousness that He is after" (Curtis 2002: 132).

Minister Farrakhan both perpetuated and further interpreted the metaphysical doctrines of Elijah Muhammad. The Mother Plane, or Mother Ship, played an especially important role in Farrakhan's thought and religious experience. In 1985, while in Mexico, Farrakhan described a religion vision in which he was transported to the Mother Ship, where he heard the voice of Elijah Muhammad. This spiritual vision was interpreted as a sign that God had chosen Farrakhan to lead his people in the final days. In the twenty-first century, Farrakhan made an alliance with the Church of Scientology, and various members of the NOI engaged in a Scientology practice called auditing, which focuses on self-knowledge. The two organisations' interest in science, technology, and especially extra-terrestrial beings became a common ground for cooperation, and demonstrated the seriousness of the NOI's long history as what some students of new religious movements have called "UFO religion" (Curtis 2016).

In viewing Farrakhan and the NOI as beyond the pale of Sunnī Islamic orthodoxy and US liberalism in the twentieth-first century, critics sometimes missed the important changes that Farrakhan introduced to the NOI movement since recreating the group in the late 1970s. While still maintaining the NoI's unique Islamic theology, Farrakhan also introduced traditional Islamic Friday congregational prayers at Mosque Maryam. Like W.D. Mohammed, he asked believers to celebrate the month of fasting not during Christmas time but during the regular Islamic month of Ramadan. He invited W.D. Mohammed to NOI events, and members of both W.D. Mohammed's and Farrakhan's communities have worked together on various projects, including contemporary efforts to insert a strong African American voice into discussions of Muslim American identity. The NOI has cooperated across racial lines, especially with 
other new religious movements, and remains an important religious organisation and social institution in African America (Gardell 1996).

\section{$5 \quad$ Conclusion}

As a movement, the NOI has remained a vital element of the US religious scene for decades. During that time, the NOI has changed the course of US history through its political activities. Joining many Muslims and the voices of African, Asians, and Latin Americans, the NOI rose to prominence as a part of a broader wave of opposition to white supremacy and neocolonialism. It was also a small, but vibrant new religious movement that developed a unique form of Islamic religion practiced by hundreds of thousands of African Americans since 1930. Its legacy not only encompasses those who have remained committed to the religious prophecies of Elijah Muhammad but also those African Americans Muslims who have transitioned from the NOI to African American Sunnī Muslim communities.

\section{References}

Clegg, C.A. III. 1997. An Original Man: The Life and Times of Elijah Muhammad. New York: St. Martin's Press.

Curtis, E.E. IV. 2002. Islam in Black America. Albany, NY: State University of New York Press.

Curtis, E.E. IV. 2006. Black Muslim Religion in the Nation of Islam, 1960-1975. Chapel Hill, NC: University of North Carolina Press.

Curtis, E.E. IV. 2013. "The Black Muslim Scare of the Twentieth Century: The History of State Islamophobia and Its Post-9/11 Variations." In C.W. Ernst ed., Islamophobia in America: The Anatomy of Intolerance. New York: Palgrave Macmillan.

Curtis, E.E. IV. 2015. "My Heart Is in Cairo: Malcolm X, the Arab Cold War, and the Making of Islamic Liberation Ethics." Journal of American History. 102:3, 775-798.

Curtis, E.E. IV. 2016. "Science and Technology in Elijah Muhammad's Nation of Islam: Astrophysical Disaster, Genetic Engineering, UFOs, White Apocalypse, and Black Resurrection." Nova Religio: The Journal of Alternative and Emergent Religions. 20:1, $5^{-31 .}$

Evanzz, K. The Messenger: The Rise and Fall of Elijah Muhammad. New York: Vintage. Gardell, M. 1996. In the Name of Elijah Muhammad: Louis Farrakhan and the Final Call. Durham, NC: Duke University Press.

Lincoln, C.E. 1961. The Black Muslims in America. Boston, MA: Beacon Press. 
Muhammad, E. 1965. Message to the Blackman in America. Chicago: Muhammad Temple No. 2.

Muhammad, E. 1972. How to Eat to Live. Book 2. Reprint, Newport, VA: National Newport News and Commentator.

Muhammad, E. 1973. The Fall of America. Reprint, Newport, VA: National Newport News and Commentator.

Turner, R.B. 2003. Islam in the African-Experience. Bloomington, IN: Indiana University Press. 